\title{
COVID-19 pandemic and agriculture in Romania: effects on agricultural systems, compliance with restrictions and relations with authorities
}

\author{
Gheorghe Cristian Popescu ${ }^{1}$ (D) Monica Popescu² ${ }^{\text {(D) }}$
}

Received: 8 December 2020 / Accepted: 31 October 2021 / Published online: 30 November 2021

(c) International Society for Plant Pathology and Springer Nature B.V. 2021

\begin{abstract}
Like most economic sectors, agriculture has been significantly affected by the COVID-19 pandemic. This study was designed to understand the impact of the initial stages of the pandemic on the agricultural sector in Romania. A web-based research study of farmers was conducted using an online questionnaire. Participants $(n=148)$ were self-selected, by answering the questionnaire online. The results highlighted that the pandemic was having an impact on agricultural costs, labor, farm management and food security. Among the farmers who were asked to describe the effects of the COVID-19 pandemic on delays with agricultural work, only $35.1 \%$ indicated that they had not registered delays. When farmers were asked if they anticipated a future increase in costs in agriculture as a result of the COVID-19 pandemic, $45.9 \%$ of respondents felt that costs would increase. Fifty-seven percent of participants reported that they would continue to apply measures to reduce the impacts of the pandemic. Our findings and analysis indicated that agricultural systems were vulnerable and that the agricultural sector must be closely monitored and supported to maintain food security in times of crisis. For food security and better resilience of agri-food systems in Romania, the study identified needs for more automation and mechanization in farms, digital solutions for the public and private sector and continuous dialogue between farmers and authorities. We suggest the pandemic can be an opportunity for the reevaluation of agricultural production systems in Romania and beyond, and for the development of more innovative strategies, sustainable practices and digital solutions in agriculture.
\end{abstract}

Keywords Agri-food systems · Agricultural policies · COVID-19 pandemic $\cdot$ Farmers $\cdot$ Food security

\section{Introduction}

Romania has the eighth largest land area and the sixth largest population in the European Union. Much of the country has good potential for agriculture. Agriculture is one of the most important areas of activity in the economy, but like most economic sectors, it has been significantly affected by the COVID19 pandemic. Providing food for the population is a priority and ongoing necessity, which is why, especially during the pandemic period, people from the agricultural sector have been considered

Gheorghe Cristian Popescu

Monica Popescu

monica_26_10@yahoo.com

1 Department of Applied Sciences and Environmental Engineering, University of Pitesti, 110040 Pitesti, Romania

2 Department of Natural Sciences, University of Pitesti, 110040 Pitesti, Romania as essential workers. Farmers have worked and continued to provide food. This study was designed to understand the ongoing impact of the COVID-19 pandemic on agriculture in Romania.

The COVID-19 pandemic and associated mitigation management has led to widespread doubts about the resilience and vulnerability of food systems in many parts of the world, with consequences for food security (see Ahmed et al., 2020). The current COVID-19 pandemic has disrupted multiple aspects of global supply chains in the agri-food sector (Gutiérrez-Moya et al., 2021). Torero (2020) noted that the pandemic has adversely affected access to agricultural inputs, agricultural technologies, and labor. Early in the pandemic, Lal (2020) predicted that COVID-19 would create food insecurity in both developed and developing countries because of disruption in food supply chains and restrictions imposed by authorities. By affecting global agricultural input and output chains, Tougeron and Hance (2021) noted that the COVID-19 pandemic has intensified food insecurity worldwide. McArthur and McCord (2017) underlined that 
key agricultural inputs to crop yield such as fertilizer, seeds, and water may be affected. In Europe, the production, distribution and marketing of fruits and vegetables has been especially disrupted by the pandemic (Tougeron \& Hance, 2021). Akter (2020) reported that stay-at-home restrictions in Europe have influenced food prices and food distribution, which may affect food security. Restrictions during the pandemic have fragmented food distribution systems (Ihle et al., 2020). Accordingly, central banks and government agencies have taken measures to stimulate economies (Akhtaruzzaman et al., 2020).

Expected effects of the pandemic were not seen in some areas, but may be delayed. For example, Deaton and Deaton (2020) examined the effect of the COVID-19 pandemic on Canadian food security using three variables: farm financial stability, transportation and international exchange. Capital flows, maintaining transportation and international exchange are strategic measures to ensure food availability in the longer run. These authors reported that despite restrictions over many months, food prices were stable and there were adequate supplies of food at least for the short term. They also showed that many farmers took out bank loans and that repayments needed to be postponed in order to support farmers to ensure stability in production. Ker and Cardwell (2020) studied the effects of income on food demand during the pandemic resulting from a slowdown in economic growth. The main effects of the global pandemic were represented by changes to consumer behavior, costs of transactions and employment. Some countries have recently considered or even adopted measures banning the export of food.

Several authors have suggested that the pandemic offers opportunities for the future. Sigala (2020) noted that while health strategies and measures implemented during the COVID-19 crisis would have a significant international economic impact, the post-pandemic period should be an opportunity for new social and economic activities. For example, the renewable and recycled carbon fuel industry and agroforestry sectors have the capacity and technologies to produce enough biomass and waste to generate energy in a sustainable way (Chiaramonti \& Maniatis, 2020).

Workers are vital for a stable food supply; maintaining their health and productivity during the COVID-19 pandemic has been a key challenge. Difficulties in securing labor for agriculture and reducing human contact to limit the spread of the virus have necessitated the identification of alternative solutions such as the use of drones or driverless agricultural machinery, unpiloted vehicles and investing in other new agriculture technologies which can adapt to the new challenges. For example, Solomon et al. (2020) suggested strategies to reduce the impact of the pandemic on the sugar industry, such as improving the mechanization of sugar crops and targeting technology towards greater sustainability. Bhavani and Gopinath (2020) noted that it was time to redesign food systems in a safe, healthy and sustainable way, such as by empowering small farmers who have essential roles for local communities. Kumar et al. (2020) proposed the agri-food sector in India be reformed to be more resilient in times of crisis, and highlighted the importance of digital solutions for agriculture, reasonable working conditions, and decentralized food systems.

While many studies have focused on the possible impacts of the COVID-19 pandemic on the agricultural sector, very few have attempted to examine the effects of the pandemic on agriculture through direct surveys with local farmers and the analysis of their responses, impressions and expectations. The purpose of this study was to evaluate the impact of the ongoing COVID-19 pandemic on agriculture in Romania by means of a web survey of farmers using an online questionnaire.

\section{Methodology}

\subsection{Experiment description and survey development}

The study was conducted by the University of Pitesti, Romania. A survey, comprising of a qualitative questionnaire, was undertaken to investigate the impact of the COVID19 pandemic on the agricultural system in Romania. The study was conducted in the South Muntenia region (34,453 $\mathrm{km}^{2} ; 14.5 \%$ ) of the country, with seven counties (Arges, Calarasi, Dambovita, Giurgiu, Ialomita, Prahova and Teleorman). South Muntenia is the second most inhabited region in Romania with most of its population living in rural areas. Agriculture is very important in this region, which comprises $80.2 \%$ arable land. Agriculture in South Muntenia is very diverse, and includes vegetable growing, fruit growing, viticulture, cereal cropping and animal husbandry. The web survey was based on an online questionnaire developed using the SurveyPlanet ${ }^{\circledR}$ software. The survey included 28 questions, of which 26 were multiple-choice questions and two were optional essay questions. The optional essay items were incorporated in the questionnaire to investigate the opinions of farmers about other measures they had to take to mitigate the effects of the COVID-19 pandemic and the measures they thought the state should take to support the agricultural sector. All multiple-choice questions were answered by the 148 farmer respondents who participated in the survey. Twelve respondents answered the optional essay questions. The characterization of the target group was performed by three questions covering basic socio-demographic characteristics: gender, domicile, and age. The questionnaire 
was not public. Participants were self-selected, by answering the questionnaire.

We identified the farmers mainly from our database of farmers, others were recommendations from agricultural institutions or associations, and others from farmers' personal networks. The dissemination plan for the survey was to use web-based online facilities and transmission from participant to participant. A web link to the online survey was sent to farmers via different online platforms using private messages as e-mails, in Facebook ${ }^{\mathrm{TM}}$ Messenger or What$\mathrm{sApp}^{\mathrm{TM}}$. The web link was distributed to official organizations related to agriculture. Participants were encouraged to share the survey with farmers in their personal networks. In order to evaluate the impact of the pandemic on farmers, 20 items were devised with answers according to the fivepoint Likert-type scale. These 20 items consisted of affirmations, and the respondents assessed their agreement with the specified statement, from strong disagreement to strong agreement using the following variants: 1-Strongly disagree, 2-Disagree, 3-Do not agree, do not disagree, 4-Agree, 5 -Strongly agree.

The survey covered the following research areas:

- the influence of the COVID 19 pandemic on the agricultural system;

- level of satisfaction regarding measures applied by authorities for the management of the COVID-19 pandemic;

- compliance with social distance and protection rules;

- relationship with public and financial institutions during the pandemic;

- the role of associative structures and digitalization in crisis situations; and

- access to social networking or other online platforms for sale of agri-products.

The development of the questionnaire took place during the COVID-19 pandemic. Its construction was based on the documented measures and regulations adopted by Romania for the control of the COVID 19 pandemic during the state of emergency and alert. Data related to the pandemic in
Romania are publicly available from the Romanian National Institute of Public Health and the National Center for Surveillance and Control of Communicable Diseases in Romania. The questionnaire-based survey was conducted during the pandemic alert state from May to July 2020, which was after the initial emergency period in Romania.

\subsection{Data protection, participation consent, and data analysis}

The questionnaire had an introductory paragraph outlining the data protection measures, consent of participation, as well as the purpose of the study. Participants were assured that all data collected would be used for research purposes only. Although participants provided some information to allow their selection, for example about farming, their participation was anonymous; participants were not permitted to provide personal data. Participants' answers were anonymous and confidential. The web link was sent to farmers via a private message. Participants could not go online on an open website to complete the survey. During the process of completing the questionnaire, participants could withdraw at any time, with only completed questionnaires saved. One hundred and forty-eight complete questionnaires were collected. The data obtained were processed, analyzed and interpreted in Microsoft Excel 2019.

\section{Results}

\subsection{The COVID-19 pandemic in Romania}

The timeline of COVID-19 events in Romania is presented in Fig. 1. The first case in Romania was identified on February 26, 2020. The number of confirmed cases with SARS-CoV-2 infection started to increase and this led to the adoption of the state of emergency in Romania. In order to control and prevent the spread of COVID-19 in Romania, on March 16, 2020, the President of Romania issued Decree no. 195/2020, which imposed a state of emergency for one month. The state of emergency was extended for
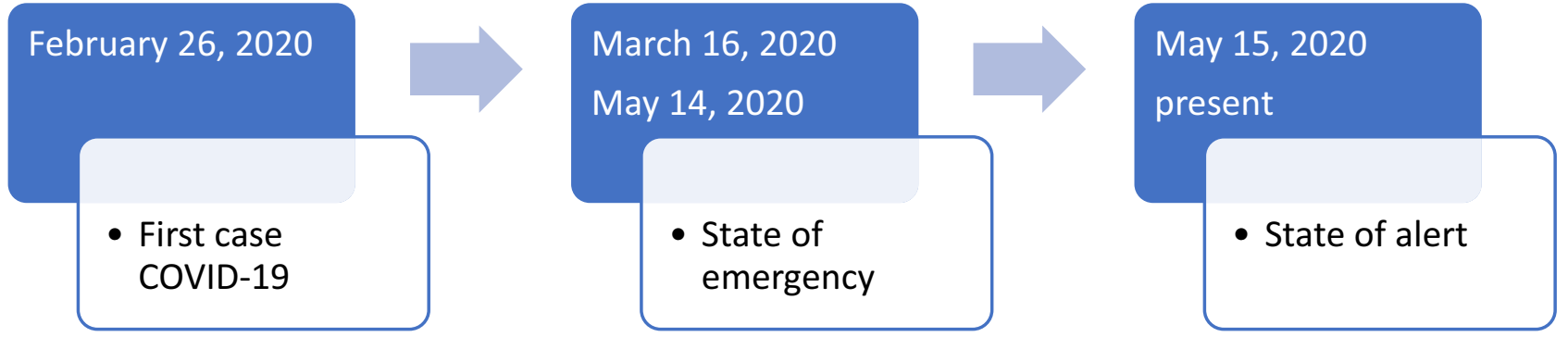

Fig. 1 Timeline of COVID-19 management in Romania 
another month, until May 14, 2020, by the Decree of the President of Romania no. 240/2020. During the two months of emergency, 12 military ordinances were adopted, which included a series of measures and obligations to prevent the spread of COVID-19 coronavirus disease. Starting from May 15 , to keep the epidemic under control, Romania adopted a state of alert, which is a regulation provided by specific legislation, clarifying how to act in the event of an epidemic. Currently, the state of alert is still present in Romania and measures, restrictions and recommendations are applied to prevent the spread of COVID-19. The data collected in this study all relate to the period of the initial state of emergency in Romania.

To effectively manage the pandemic and reduce the spread of the virus, Romania undertook a series of measures which included hygiene and health measures, limiting contact between people, mobility and socioeconomic restrictions (Fig. 2). During the state of emergency and alert, emphasis was put on preparation of the health system to address the pandemic, the provision of protective equipment and elaboration of procedures for pandemic management. In Romania, many of public services became digital and support measures were taken in line with EU directives and common agricultural policies to reduce the impact of COVID-19 on agri-food systems.
Table 1 Demographic characteristics of sample of respondents to COVID-19 questionnaire

\begin{tabular}{lll}
\hline Gender (\%) & $\begin{array}{l}\text { male } \\
\text { female }\end{array}$ & $\begin{array}{l}56.8 \\
43.2\end{array}$ \\
\hline Domicile (\%) & urban & 34 \\
& rural & 66 \\
Age (\%) & $18-25$ & 10.8 \\
& $26-40$ & 44.6 \\
& $46-65$ & 43.2 \\
& $>66$ & 1.4 \\
\hline
\end{tabular}

\subsection{Effects of COVID-19 pandemic on agricultural system}

The online survey reported in this paper was focused on farmer opinions. The socio-demographic variables included gender, domicile and age (Table 1). Among the participants, $56.8 \%$ were male and $43.2 \%$ were female. Most of the participants belong to the age group $26-40$ years (44.6\%). Only $1.4 \%$ of respondents were aged $>65$ years old. More than $65 \%$ of participants were from rural areas. There are many farmers with domicile in urban areas. Most of them work small agricultural lands but a few have big farms with part of production marketed in towns. In recent years, some communes in the counties we studied have become towns, from an administrative point of view, but inside of these "towns"
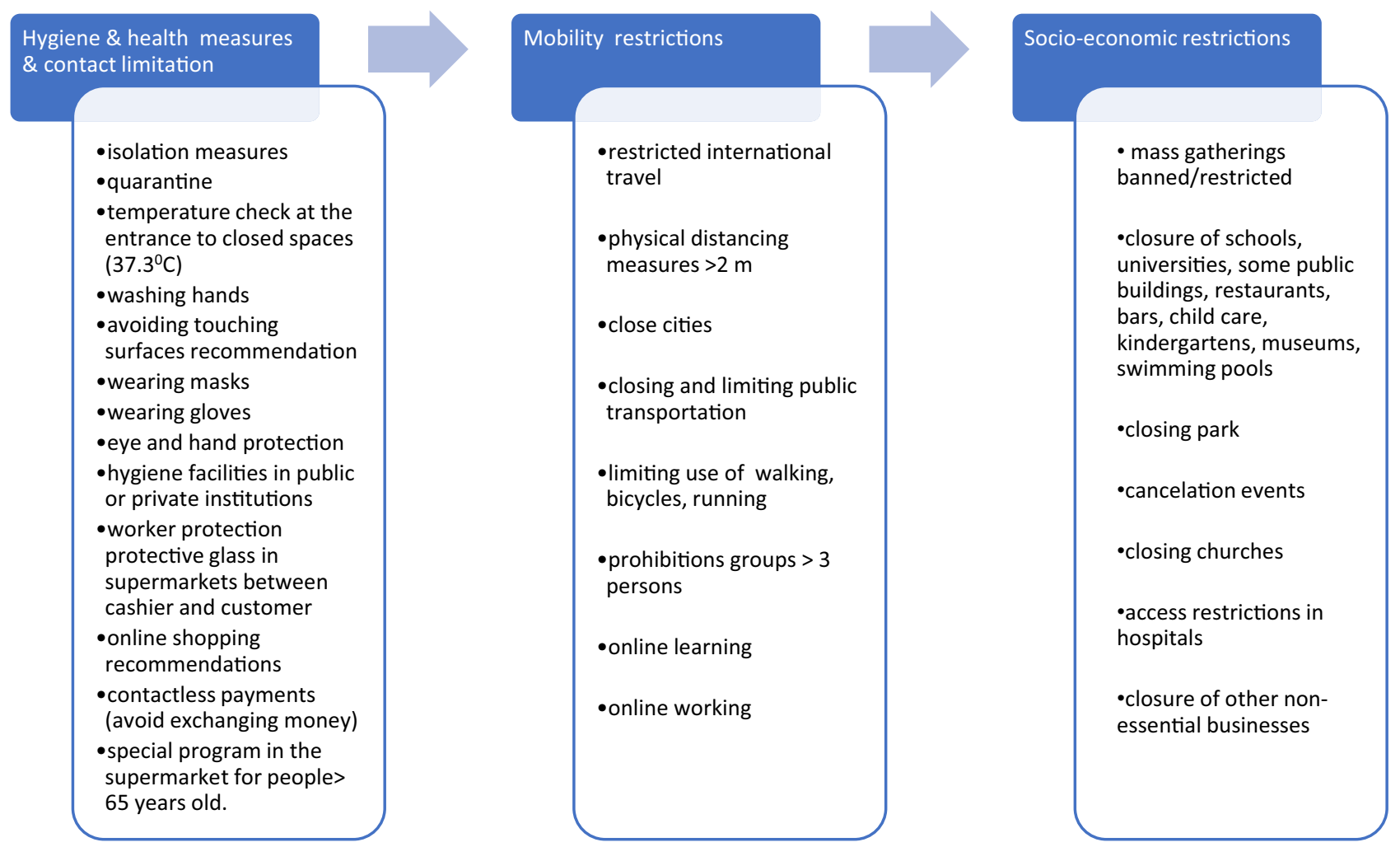

Fig. 2 Main measures and recommendations to prevent the spread of COVID-19 
are large agricultural areas. Most towns in Romania have some agricultural land.

Timely execution of agricultural work activities is essential for the performance of agriculture. Delays in some activities due to problems with agricultural inputs or labor shortage will lead to lower crop yields. The data in Table 2 are the recorded scores in responses to the possible delay of agricultural work, cancelation of investments, delays in receiving agricultural inputs and lack of, or insufficent labor in farms. From the participants that described the effect of the COVID-19 pandemic on the delay of agricultural work, $35.1 \%$ of respondents confirmed that they did not have delays, while $18.9 \%$ agreed that they had delays. Additionally, respondents were asked to report the impact of the pandemic on the cancelation of investments or other agricultural activities, and $24.3 \%$ of respondents noted that they had no cancelations. However, $23 \%$ of participants reported cancelation of investments or other agricultural work. Twenty-three percent of respondents noted that they strongly disagreed with the assertion that the pandemic had led to delays in receiving agricultural inputs, while 5.4\% strongly agreed. Regarding the lack of labor or deficiency of the labor force during the pandemic, many the respondents (37.7\%) agreed that they had difficulties. The responses of participants related to the use of online platforms by farmers are in Table 2. Over $32 \%$ of producers accessed social networks or other online platforms for the sale of agricultural products. However, more than $40 \%$ of farmers did not use social networks or other online platforms to sell products.

The recorded scores in responses related to the sale of agricultural products during the pandemic are presented in Table 3. When asked if they had better sales as a result of COVID-19, only $9.5 \%$ of respondents agreed, although $18.9 \%$ of respondents noted that they had improved their sales directly from the farm. Mobility restrictions, as well as the closure of restaurants, reduced the sales volume of agri-food products. Thirty-two percent of the producers responded that they had difficulties in dealing with
Table 3 The sale of agricultural products during the pandemic in Romania

\begin{tabular}{lcll}
\hline & Better & Weaker & $\begin{array}{l}\text { Neither } \\
\text { better nor } \\
\text { weaker }\end{array}$ \\
\hline $\begin{array}{l}\text { A.How was the sale of } \\
\text { agricultural products } \\
\text { during the pandemic? }\end{array}$ & 9.5 & 73 & 17.5 \\
$\begin{array}{l}\text { B.Sale of agricultural } \\
\text { products directly from } \\
\text { the farm }(\%)\end{array}$ & 18.9 & 56.8 & 24.3 \\
\hline
\end{tabular}

financial institutions, while 57\% did not report having difficulties.

Results from agricultural producers about the impact of COVID-19 on stocks of agricultural inputs and prices of fuel, agricultural inputs and agri-food products during the pandemic are in Table 4. The majority of producers noted a lower price for fuels ( $92 \%$ of respondents) over the survey period. Just a few respondents noted a higher price for fuel. More than $40 \%$ of producers strongly disagreed or disagreed when they were asked to indicate if the COVID-19 pandemic had increased the price of agricultural inputs (seeds, pesticides, fertilizers). At the same time, $25.7 \%$ of farmers agreed and $5.4 \%$ strongly agreed that the prices of agricultural inputs had risen. Seventy-six percent of participants estimated that the price of agrifood products increased as a result of the pandemic, while just six percent of respondents answered that prices neither increased nor decreased. Nearly $38 \%$ of agricultural producers did not consider securing stocks of agricultural inputs, but more than $25 \%$ of farmers agreed to stock up on agricultural inputs. Overall our results show various vulnerabilities in the agricultural systems and most farmers experienced difficulties with labor and the use of agricultural technologies during the initial period of COVID-19 in Romania.

Table 2 The effect of COVID-19 pandemic in Romania: (A) delay of agricultural works, (B) cancelation of investments, (C) delays in receiving agricultural inputs, (D) labor in farms, (E) access of online platforms

\begin{tabular}{|c|c|c|c|c|c|}
\hline & $\begin{array}{l}\text { Strongly } \\
\text { disagree }\end{array}$ & Disagree & $\begin{array}{l}\text { Do not } \\
\text { agree, do } \\
\text { not disagree }\end{array}$ & Agree & Strongly agree \\
\hline A.The COVID-19 pandemic delayed agricultural works (\%) & 17.6 & 35.1 & 27.5 & 18.9 & 0.9 \\
\hline $\begin{array}{l}\text { B.The COVID-19 pandemic generated the cancelation of some agricultural works } \\
\text { or investments }(\%)\end{array}$ & 20.3 & 24.3 & 25.6 & 23.0 & 6.8 \\
\hline $\begin{array}{l}\text { C.The COVID_-19 pandemic caused delays in receiving agricultural inputs } \\
\text { (seeds, pesticides, fertilizers) }(\%)\end{array}$ & 23.0 & 33.7 & 20.3 & 17.6 & 5.4 \\
\hline D.The coronavirus pandemic generated difficulties in ensuring labor in farms (\%) & 9.5 & 31.1 & 12.2 & 37.7 & 9.5 \\
\hline $\begin{array}{l}\text { E.During this period, have you tried to access social networks or other online } \\
\text { platforms for selling agricultural products? }\end{array}$ & 13.5 & 27 & 27 & 25.7 & 6.8 \\
\hline
\end{tabular}


Table 4 Stocks of agricultural inputs and prices during COVID-19 pandemic: (A) price of fuels, (B) agri-food products price, (C) agricultural inputs price, (D) stocks of agricultural inputs

\begin{tabular}{|c|c|c|c|c|c|}
\hline & \multicolumn{2}{|l|}{ Higher } & Lower & \multicolumn{2}{|c|}{$\begin{array}{l}\text { Neither higher nor } \\
\text { lower }\end{array}$} \\
\hline A.Price of fuel compared to the period before the COVID-19 pandemic & 2 & & 92 & 6 & \\
\hline \multirow{2}{*}{$\begin{array}{l}\text { B.Price of agri-food products (dairy products, meat products, bakery, fruits, vegetables) } \\
\text { during COVID-19 pandemic }\end{array}$} & 76 & & 18 & 6 & \\
\hline & $\begin{array}{l}\text { Strongly } \\
\text { disagree }\end{array}$ & Disagree & $\begin{array}{l}\text { Do not } \\
\text { agree, } \\
\text { do not } \\
\text { disagree }\end{array}$ & Agree & Strongly agree \\
\hline $\begin{array}{l}\text { C.The COVID-19 pandemic generated an increase in the prices of agricultural } \\
\text { inputs (seeds, pesticides, fertilizers) }\end{array}$ & 10.8 & 35.1 & 23 & 25.7 & 5.4 \\
\hline $\begin{array}{l}\text { D.Do you consider providing stocks of agricultural inputs (seeds, planting material, } \\
\text { pesticides, diesel, fertilizers, etc.)? }\end{array}$ & 6.8 & 37.8 & 24.3 & 25.7 & 5.4 \\
\hline
\end{tabular}

\subsection{Agricultural compliance with social distance and protective rules, satisfaction with pandemic management measures applied by authorities and the relationship with public/ financial institutions during pandemic}

In Table 5 we give the scores obtained when farmers were asked about the role of agricultural associations to reduce the impact of the pandemic (A), the role of digitalization in times of pandemic (B), the role of improving agricultural policies for food security (C), and if an agri-food crisis could be generated by the developing effects of COVID-19 (D). Of the participants that were asked to describe the role of digitalization for the agricultural sector, more than $65 \%$ agreed or strongly agreed that digitalization was essential. Farmers agreed that digital solutions had a positive impact on their business and were interested to use such digital practices. Only $8.1 \%$ of participants considered the role of digital solutions to be minimal.

When asked to give an opinion on the role of agricultural associations in times of crisis, $27 \%$ of respondents agreed that agricultural associations can mitigate the effects of a crisis, while 5.4\% strongly agreed with this. Similar percentages were recorded for those who did not agree or strongly disagreed. Thus, the study showed that a significant percentage of farmers believed that agricultural associations have an important role in mitigating the negative effects of crisis situations. Of the respondents, $45.9 \%$ strongly agreed that Romania needed much better agricultural policies to reduce dependency on imports. Very few respondents (2.7\%) noted that Romania did not need additional agricultural policies to reduce dependency on imports. When agricultural producers were asked if an agri-food crisis could be a result of COVID-19, $25.7 \%$ of respondents disagreed, but $44.6 \%$ of participants agreed.

Data collected from respondents about the relationship with financial (A) and public (B) institutions during the pandemic are presented in Table 6. When agricultural producers were asked if they encountered any difficulties with financial institutions as a result of COVID-19, 10.8\% responded that they agreed they had difficulties, while $6.8 \%$ noted that they strongly agreed. More than $50 \%$ did not report having difficulties in dealing with financial institutions. When asked about the relationship with public institutions because of

Table 5 Role of associative agricultural structures (A); Role of digitalization in times of pandemic (B); Policies for food security (C); Agri-food crisis could be generated by the effect of coronavirus (D)

\begin{tabular}{llllc}
\hline & Not at all & Only a little & To some extent & Rather much \\
\hline $\begin{array}{l}\text { A. Do the associative agricultural structures respond better to a possible } \\
\text { sanitary / economic / food crisis? }\end{array}$ & 5.4 & 27 & 35.2 & 27 \\
$\begin{array}{l}\text { B.To what extent do you appreciate that digitalization helps the } \\
\text { agricultural sector? }\end{array}$ & 8.1 & 12.2 & 13.5 & 45.9 \\
$\begin{array}{l}\text { C.To what extent do you consider it necessary for Romania to focus } \\
\text { even more on policies that reduce dependence on imports (food } \\
\text { security)? }\end{array}$ & 2.7 & 12.2 & 6.8 & 32.4 \\
$\begin{array}{l}\text { D.To what extent do you appreciate that Romania will have an agri- } \\
\text { food crisis generated by the effects of the Covid-19 pandemic? }\end{array}$ & 2.7 & 25.7 & 16.2 & 45.9 \\
\hline
\end{tabular}


Table 6 Relationship with financial (A) and public (B) institutions; compliance with the social distance and protective rules (C \& D)

\begin{tabular}{|c|c|c|c|c|c|}
\hline & $\begin{array}{l}\text { Strongly } \\
\text { disagree }\end{array}$ & Disagree & $\begin{array}{l}\text { Do not } \\
\text { agree, do } \\
\text { not disagree }\end{array}$ & Agree & Strongly agree \\
\hline A.Have you encountered difficulties in dealing with financial institutions? & 13.5 & 37.8 & 31.1 & 10.8 & 6.8 \\
\hline B.Have you encountered difficulties in your relationship with public institutions? & 13.5 & 31.1 & 32.4 & 14.9 & 8.1 \\
\hline C.Were social distance measure applied in farms and for selling agri-products? & 8.1 & 16.2 & 9.5 & 52.7 & 13.5 \\
\hline $\begin{array}{l}\text { D.Were protection rules (gloves, mask, etc.) applied in farms and for selling agri- } \\
\text { products? }\end{array}$ & 6.8 & 17.6 & 5.4 & 54 & 16.2 \\
\hline
\end{tabular}

COVID-19, 44\% of the respondents did not report having difficulties dealing with public institutions, while $14.9 \%$ of the farmers agreed and $8.1 \%$ strongly agreed that they encountered difficulties. These results highlight that communication with all institutions involved in the agri-food sector played an essential role in the successful implementation of agricultural policy. Authorities must have direct meetings and continuous dialogue with farmers and agricultural and food industry associations.

Participants were asked if protection rules (gloves, mask, etc.) and social distance measures were applied in farms and when selling agri-products (Table 6). Of the farmers, $52.7 \%$ agreed and $13.5 \%$ strongly agreed that they applied measures of social distancing in the farm and during the process of selling agricultural products. Most farmers reported they
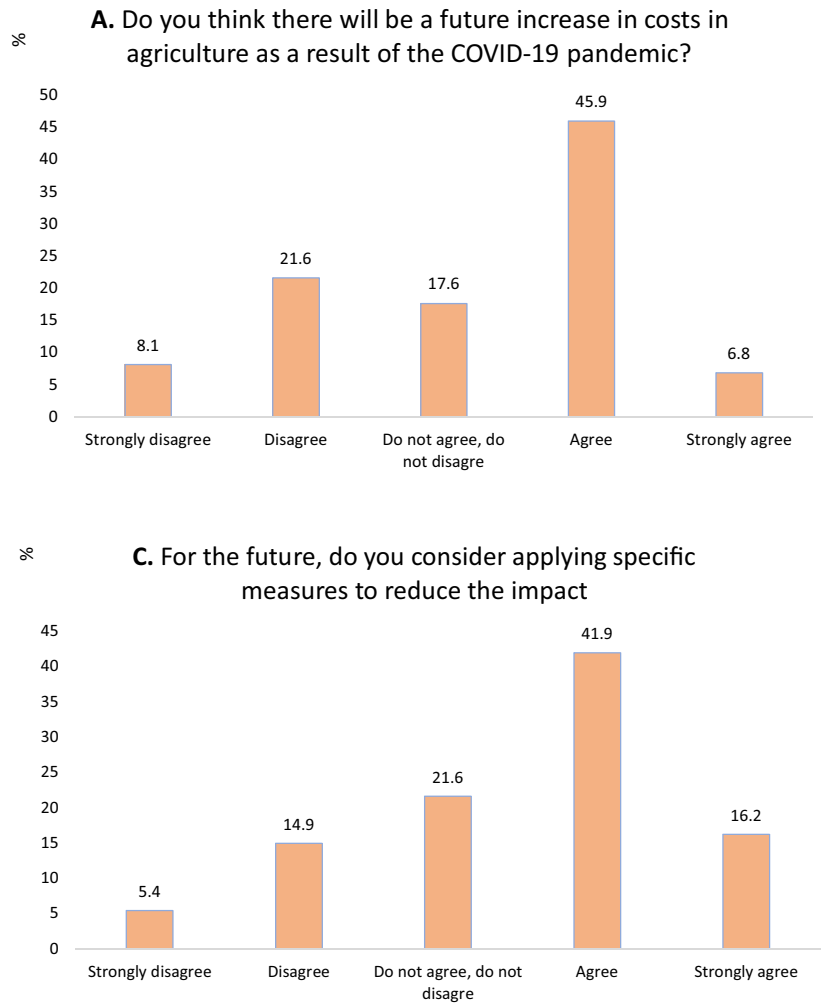

had quickly adapted to the new public health requirements and complied with their application on farms. However, almost $25 \%$ of participants reported that they did not apply social distance measures on the farm and in the process of selling agricultural products. Regarding other protection rules (especially wearing a mask and gloves), the majority of participants reported compliance with these measures $(54 \%=$ agree $; 8.1 \%=$ strongly agree $)$.

The recorded scores in responses related to future agricultural costs and agri-food product prices because of COVID19 , the application of specific measures to reduce the crisis impact, as well as responses about the level of satisfaction with measures imposed by the authorities are in Fig. 3. When participants were asked if they anticipated a future increase in costs in agriculture as a result of the COVID-19

\section{B. Do you think there will be a future increase in agri-food prices due to the COVID-19 pandemic?}
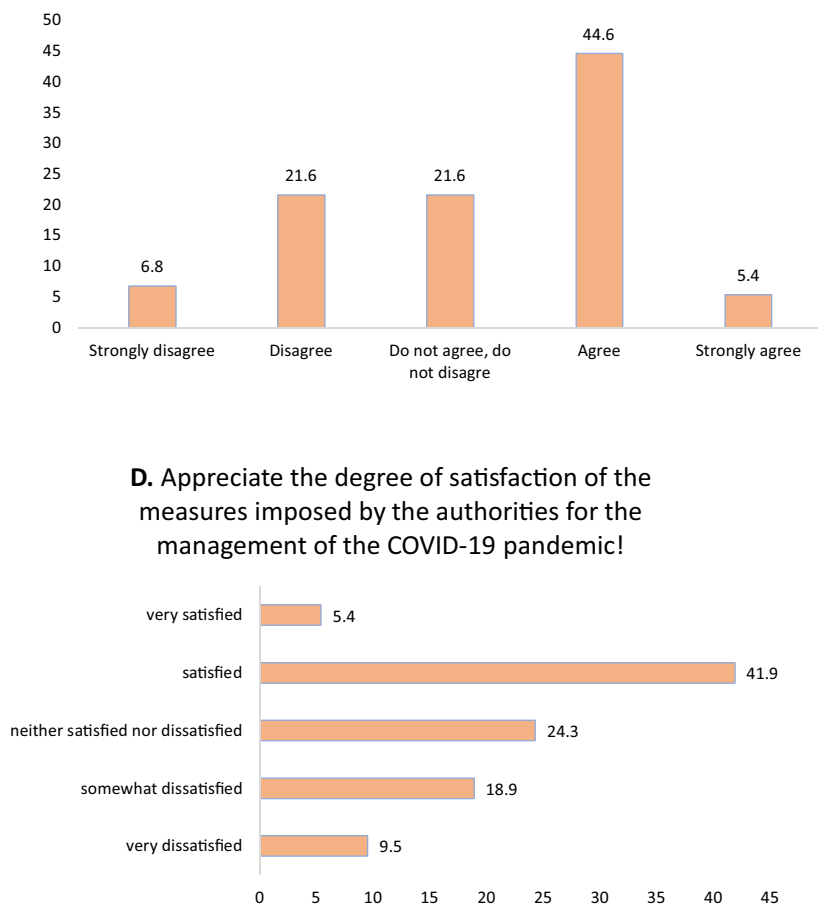

Fig. 3 Agreement and satisfaction with COVID-19 pandemic management measures in Romania. Future agricultural costs (A) and agri-food prices (B); Specific measures to reduce crisis impact (C); Level of satisfaction with the measures imposed by the authorities (D) 
pandemic, $45.9 \%$ agreed that costs would increase, while $21.6 \%$ disagreed. A few participants neither agreed nor disagreed with the price increase. Over $44 \%$ of producers agreed that there would be an increase in agri-food prices due to the COVID-19 pandemic in the future. However, more than $27 \%$ of respondents were of the opinion that the pandemic would not generate an increase in the prices of agricultural products. Fifty-seven percent of agricultural producers reported that they would continue to apply measures to reduce the impact of the pandemic. Just a few respondents (5.4\%) strongly claimed that they would not take measures to reduce the impact of the pandemic. At the end of the survey, participants were asked to assess the degree of satisfaction with the measures imposed by the authorities. The responses of the participants were: very satisfied (5.4\%), satisfied (41.9\%), neither satisfied nor dissatisfied (24.3\%), somewhat dissatisfied (18.9\%), and very dissatisfied (9.5\%).

Answers to the optional essay questions are summarized in Fig. 4. Participants emphasized the importance of reducing bureaucracy, accessing European funds, fiscal facilities and strategies for food security, and clear agri-food policy. For most rural areas in Romania, support to the development of small farms and family farms is essential and farmers emphasized this aspect in their responses. Romanian agriculture is dominated by small family farms and most of the participants in our survey had these types of farms. The study emphasized that a proactive relationship with agricultural actors in public institutions (especially in times of crisis), the support of small and medium-sized farms, and the provision of digital solutions for agriculture and public services could ensure the stability of food security in the country.

\section{Discussion}

Identifying solutions and strategies for improved resilience of agricultural systems and ensuring better access to food is an ongoing concern for agricultural policymakers. Our study aimed to analyze the impact of the initial stages of the COVID-19 pandemic on Romanian farmers by means of a web survey based on an online questionnaire. The COVID19 pandemic has affected food supply chains in many parts of the world during 2020 and effects continue into 2021 . In the current study, we found the pandemic had an impact on farm labor, prices, cost and farm management in Romania during 2020. A noticeable percentage of respondents confirmed that they had delayed agricultural work because of effects of the COVID-19 pandemic. Adequate human resources are essential for the productivity of agricultural systems. Most small farms in Romania are family farms and in general in the recent past they have not had difficulties in ensuring the labor force to carry out the agricultural work on the farms.

Labour shortages for agriculture have been commonly reported to be a consequence of the pandemic in many agricultural settings around the world. For instance, in
Fig. 4 Farmers' responses to the optional essay questions on managing COVID-19 in Romania

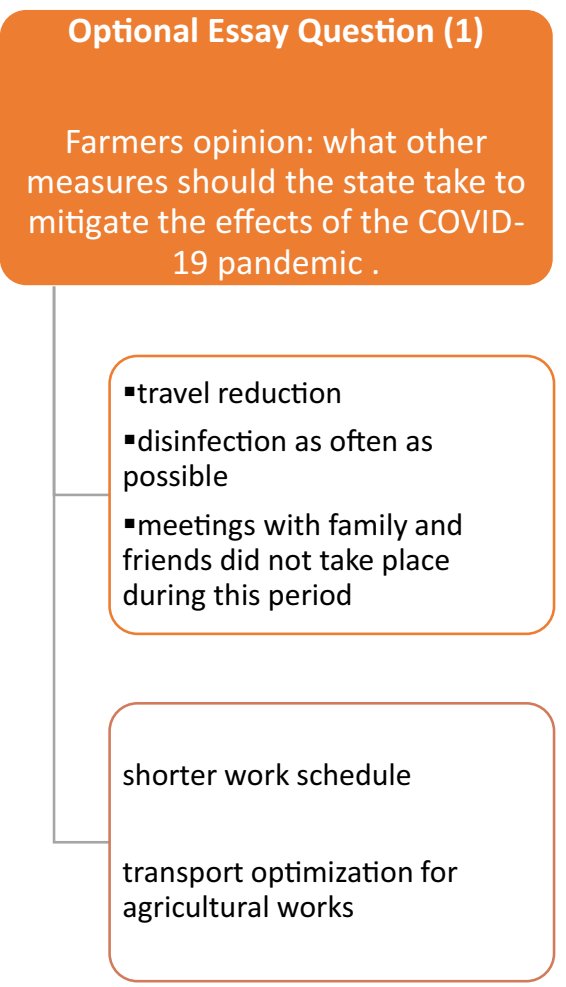


India, strawberry farmers had serious problems with their crops because they could transport the fruit to city markets, or in Peru, producers dumped large amounts of cocoa into landfills because the restaurants and hotels were closed (Torero, 2020). Also, in the United States and Canada, the closure of restaurants and hotels created difficulties for dairy farmers. The United States, Canada, Germany, Australia, Italy, France, and England all faced serious difficulties with shortages of seasonal farm workers who were unable to travel because of virus restrictions. Similar measures have been taken to manage the pandemic in many countries around the world, such as transportation restrictions, closing restaurants or hotels, and these have affected farming. Many local farmers in Romania provide agri-food products to restaurants and hotels. Our study highlighted that farmers in Romania also had difficulties in selling products or carrying out agricultural work.

For the future, such crisis situations should be anticipated and managed much more efficiently. In Romania, there are over 3.4 million agricultural holdings, with the vast majority being small farms, family farms, and subsistence farms. Given the mobility restrictions, especially the closure of restaurants and agricultural markets, and reduced purchasing power, small agricultural producers have been particularly affected. It is essential that local producers sell their products in agricultural markets in compliance with health protection rules. For this reason, the agricultural sector must be closely monitored and supported so as to ensure food security, especially in times of crisis. Our findings are in agreement with Garnett et al. (2020), who reported that the COVID-19 pandemic would continue to create problems for agricultural food systems. In this sense, our study represents a starting point and reference for the updating of food security policies and managing crises more efficiently for Romanian farmers.

Results of our study showed that accessing social networks or other online platforms for selling agricultural products is becoming very common and important among Romanian farmers. These trends are part of the digitalization of agriculture, which is increasingly present in all sectors of activity (Klerkx et al., 2019) and is a productive process in agriculture (Smith, 2020). Digitalization in agriculture provides technical optimization of agricultural production and food systems. Such practices can help shorten food chains, capitalize on local products and ensure freshness. In our study, most participants agreed that digital solutions had a positive impact on their business and they were open to using such digital practices. For farmers from Romania, the pandemic has led to greater use of digital social networks or other online platforms for selling agricultural products. Among farmers and institutions, the role of digitalization has increased and online communication tools have been used much more. Elsewhere, Christiaensen et al. (2020) noted that the pandemic would intensify digitalization in the agrifood sector.

Participants emphasized the importance of accessing European Union funds, fiscal facilities and strategies for food security. These ideas are in agreement with several other studies related to the COVID-19 pandemic in Europe and Africa. For instance, Garnett et al. (2020) reported the need for investment, digital automation, training and innovation in agricultural systems in the UK. Nchanji et al. (2021) provided survey results of the impact of the COVID-19 pandemic on agriculture and food systems in Africa. They emphasized the roles of the public sector and governments in supporting small farmers as a means to mitigate the effects on the agricultural system and food security. Laborers in farms must be given improved protective equipment and working conditions.

Petersen et al. (2020) point out that social and economic restrictions in place during the pandemic are not sustainable on a longer term. The resumption of economic activities and normal social life remains one of the objectives of the European Union (European Commission, 2020). In this regard, the European Green Deal, Farm-to-Fork Strategy, the EU Biodiversity Strategy for 2030, are all relevant for the agri-food sector and rural areas and can have a very important contribution to increasing the resilience of agricultural systems to crisis situations, but also to make European and Romanian agriculture greener and more sustainable. Through the answers given by farmers, they considered that accelerating the absorption of European funding is a good solution for managing crisis situations, such as the pandemic. We believe that new European policies and strategies much more focused on the environment and the agricultural sector will better prepare Europe and member states of the European Union for potential health, economic, environmental or social crises. Food policies should include new agricultural technologies, food subsidies, and institutions available to farmers and consumers. Arndt et al. (2020) pointed out that the pandemic has already influenced food security policies. Also, our research showed that most participants reported that they would continue to apply measures to reduce the impact of the pandemic and agreed that measures were still needed for good food security. Our interviewed farmers were aware of the roles they have in ensuring food security, and could better fulfill these when supported by concrete measures and policies.

Amjath-Babu (2020) pointed out that many of these same trends on distribution logistics, innovative labor management tools, farm mechanization, digital services, international trade management policies and institutions were essential supportive measures to mitigate the impact of the COVID-19 pandemic for developing countries as well. The global pandemic has affected agri-food systems globally. This international problem is already providing 
opportunities for societies to evaluate the vulnerabilities in their food systems and reinvent themselves to be more robust and resilient (Cable et al., 2021). Our study also emphasized the role of associative agricultural structures for a successful agribusiness, especially in situations of crisis, with many of the respondents valuing their involvement in agricultural associations.

Most respondents agreed with and complied with the pandemic management measures imposed in Romania. In terms of food security, the control of the COVID-19 pandemic requires an unprecedented proactive ongoing global approach, with international cooperation and solidarity between the states and organizations of the world. Crisis situations require the rapid adaptation and orientation of agri-food policies in order to develop effective solutions. Communication with all actors involved in the agri-food sector plays an essential role in the successful implementation of agricultural policy and needs more emphasis. Agri-food policies must be based on and result from intensified direct meetings of farmers, agricultural and food industry associations with authorities and policy makers.

\section{Conclusions}

Romania, like most countries in the world, has faced a multitude of problems caused by the COVID-19 pandemic. In this paper we demonstrated that the pandemic had a large impact on agricultural costs, labor, farm management and food security in Romania in 2020. This paper provided a comprehensive assessment of the effects of the pandemic on agricultural systems, compliance with restrictions and relations with authorities, and proposed some suggestions for the future management of such situations. Also, this study provides a good understanding of the problems and challenges faced by Romanian farmers during pandemic.

The vast majority of farmers complied with the rules for COVID-19 pandemic control and reported that they were satisfied with the measures imposed by the authorities. Farmers faced some difficulties with agricultural technology and with the sale of agri-food products.

Our findings and analysis indicated that agricultural systems in Romania were vulnerable and that the agricultural sector must be closely monitored and supported to maintain food security in times of crisis. A proactive relationship with agricultural actors in public institutions is needed. Quick responses and solutions from public administration, accelerating digitalization, adapting to challenges, supporting local farmers and investments in agricultural mechanization and innovation should help mitigate the effects of crisis situations and for the stability of food security. At the same time, such a crisis can be an "opportunity" for the evaluation of agricultural production systems, and for the development of more innovative strategies, sustainable practices and digital solutions in agriculture.

Supplementary Information The online version contains supplementary material available at https://doi.org/10.1007/s12571-021-01239-8.

\section{Declarations}

Conflict of interest The authors declare that they have no conflict of interest.

\section{References}

Ahmed, S., Downs, S. M., Yang, C., Chunlin, L., Ten Broek, N., \& Ghosh-Jerath, S. (2020). Rapid tool based on a food environment typology framework for evaluating effects of the COVID-19 pandemic on food system resilience. Food Security, 12(4), 773-778. https://doi.org/10.1007/s12571-020-01086-z

Akhtaruzzaman, M., Boubaker, S., \& Sensoy A. (2020). Financial contagion during COVID-19 crisis. Finance Research Letters 101604. https://doi.org/10.1016/j.frl.2020.101604

Akter, S. (2020). The impact of COVID-19 related 'stay-at-home' restrictions on food prices in Europe: Findings from a preliminary analysis. Food Security, 12(4), 719-725. https://doi.org/10.1007/ s12571-020-01082-3

Amjath-Babu, T. S., Krupnik, T. J., Thilsted, S. H., \& McDonald, A. J. (2020). Key indicators for monitoring food system disruptions caused by the COVID-19 pandemic: Insights from Bangladesh towards effective response. Food Security, 12(4), 761-768. https:// doi.org/10.1007/s12571-020-01083-2

Arndt, C., Davies, R., Gabriel, S., Harris, L., Makrelov, K., Robinson, S., et al. (2020). Covid-19 lockdowns, income distribution, and food security: An analysis for South Africa. Global Food Security, 26, 100410. https://doi.org/10.1016/j.gfs.2020.100410

Bhavani, R. V., \& Gopinath, R. (2020). The COVID19 pandemic crisis and the relevance of a farm-system-for-nutrition approach. Food Security, 12(4), 881-884. https://doi.org/10.1007/ s12571-020-01071-6

Cable, J., Jaykus, L. A., Hoelzer, K., Newton, J., \& Torero, M. (2021). The impact of COVID-19 on food systems, safety, and security-a symposium report. Annals of the New York Academy of Sciences, 1484(1), 3-8. https://doi.org/10.1111/nyas. 14482

Chiaramonti, D., \& Maniatis, K. (2020). Security of supply, strategic storage and Covid19: Which lessons learnt for renewable and recycled carbon fuels, and their future role in decarbonizing transport? Applied Energy, 271, 115216. https://doi.org/10.1016/j. apenergy.2020.115216

Christiaensen, L., Rutledge, Z., \& Taylor, J. E. (2020). The future of work in agri-food Food Policy. 101963. https://doi.org/10.1016/j. foodpol.2020.101963

Deaton, B. J., \& Deaton, B. J. (2020). Food security and Canada's agricultural system challenged by COVID-19. Canadian Journal of Agricultural Economics/revue Canadienne D'agroeconomie, 68, 143-149. https://doi.org/10.1111/cjag.12227

European Commission. (2020). Coronavirus: European roadmap shows path towards common lifting of containment measures. https://ec. europa.eu/commission/presscorner/detail/en/IP_20_652

Garnett, P., Doherty, B., \& Heron, T. (2020). Vulnerability of the United Kingdom's food supply chains exposed by COVID-19. Nature Food, 1(6), 315-318. https://doi.org/10.1038/s43016-020-0097-7

Gutiérrez-Moya, E., Adenso-Díaz, B., \& Lozano, S. (2021). Analysis and vulnerability of the international wheat trade 
network. Food Security, 13(1), 113-128. https://doi.org/10.1007/ s12571-020-01117-9

Ihle, R., Rubin, O. D., Bar-Nahum, Z., \& Jongeneel, R. (2020). Imperfect food markets in times of crisis: Economic consequences of supply chain disruptions and fragmentation for local market power and urban vulnerability. Food Security, 12(4), 727-734. https:// doi.org/10.1007/s12571-020-01084-1

Ker, A. P., \& Cardwell, R. (2020). Introduction to the special issue on COVID-19 and the Canadian agriculture and food sectors: Thoughts from the pandemic onset. Canadian Journal of Agricultural Economics, 68, 139-142. https://doi.org/10.1111/cjag.12245

Klerkx, L., Jakku, E., \& Labarthe, P. (2019). A review of social science on digital agriculture, smart farming and agriculture 4.0: New contributions and a future research agenda. NJAS-Wageningen Journal of Life Sciences, 90, 100315. https://doi.org/10.1016/j. njas.2019.100315.

Kumar, A., Padhee, A. K., \& Kumar, S. (2020). How Indian agriculture should change after COVID-19. Food Security, 12(4), 837-840. https://doi.org/10.1007/s12571-020-01063-6

Lal, R. (2020). Home gardening and urban agriculture for advancing food and nutritional security in response to the COVID-19 pandemic. Food Security, 12(4), 871-876. https://doi.org/10.1007/ s12571-020-01058-3

McArthur, J. W., \& McCord, G. C. (2017). Fertilizing growth: Agricultural inputs and their effects in economic development. Journal of Development Economics, 127, 133-152. https://doi.org/10.1016/j. jdeveco.2017.02.007

Nchanji, E. B., Lutomia, C. K., Chirwa, R., Templer, N., Rubyogo, J. C., \& Onyango, P. (2021). Immediate impacts of COVID-19 pandemic on bean value chain in selected countries in sub-Saharan Africa. Agricultural Systems, 188, 103034. https://doi.org/10. 1016/j.agsy.2020.103034

Petersen, E., Wasserman, S., Lee, S. S., Unyeong, G. O., Holmes, A. H., Al Abri, S., et al. (2020). COVID-19-We urgently need to start developing an exit strategy. International Journal of Infectious Diseases, 96, 233-239. https://doi.org/10.1016/j.ijid.2020.04.035

Sigala, M. (2020). Tourism and COVID-19: Impacts and implications for advancing and resetting industry and research. Journal of Business Research, 117, 312-321. https://doi.org/10.1016/j.jbusres. 2020.06 .015

Smith, M. J. (2020). Getting value from artificial intelligence in agriculture. Animal Production Science., 60(1), 46-54. https://doi. org/10.1071/AN18522

Solomon, S., Rao, G. P., \& Swapna, M. (2020). Impact of COVID-19 on Indian Sugar Industry. Sugar Tech, 22, 547-551. https://doi. org/10.1007/s12355-020-00846-7

Torero, M. (2020). Without food, there can be no exit from the pandemic. Nature, 580, 588-589. https://doi.org/10.1038/ d41586-020-01181-3

Tougeron, K., \& Hance, T. (2021). Impact of the COVID-19 pandemic on apple orchards in Europe. Agricultural Systems, 190, 103097. https://doi.org/10.1016/j.agsy.2021.103097

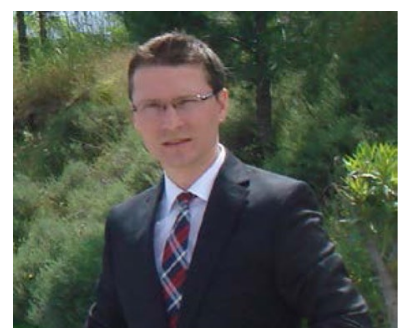

Cristian Popescu is an Associate Professor Dr. Eng. at the University of Pitesti, Romania, with over 15 years of experience in the following areas: Horticulture, Agri-Environment, Agricultural and Environmental Policies and Legislation. He holds a Bachelor's degree in Horticulture and Law, a Master's degree in Management and a Doctoral

degree in Agricultural Sciences. He also obtained an Erasmus Student Scholarships/ Scholarship for one semester in Belgium, at Ghent University, Faculty of Bioscience Engineering. He was a member and director and of Research and Educational Projects financed by the Romanian Ministry of Education and Research and manager of a project financed with European Agricultural Fund for Rural Development under the Common Agricultural Policy of European Union. He is member of national and international professional associations and reviewer for prestigious journals. He was Invited Professor and Keynote Speaker for conferences, webinars and participated in international teaching and training mobilities by Erasmus program in countries from Europe, Asia, Africa. Cristian is the author or co-author of 9 books and more than 50 papers published in international scientific journals.

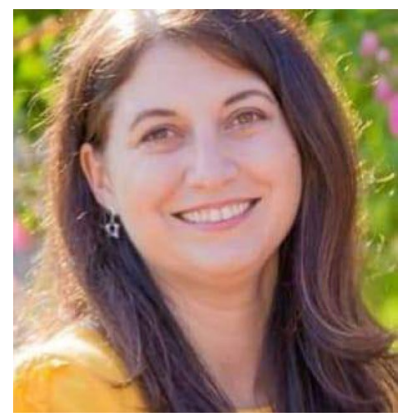

Monica Popescu is an Associate Professor PhD at the University of Pitesti, Romania, with over 20 years of experience in the areas of plant science, plant physiology, plant biology, physiological implications of agricultural technologies, and research projects. She holds a Bachelor's degree in Biology, a Doctoral degree in Biology and a specialization in project management and entrepreneurial skills. She was a member and director of Research and Educational Projects. She participated in teaching or training mobilities in Turkey, Czech Republic, Egypt, Hungary, Latvia, Spain, Portugal, Bulgaria or Italy, within the Erasmus program. She is currently Editor-in-Chief of the journal Current Trends in Natural Sciences and member in prestigious national/international professional associations: ISHS, ESNA, and IAD. She reviewed articles for some prestigious international journals. Monica is the author or co-author of 8 books and more than 60 papers published in international scientific journals. 